\title{
Human papillomavirus (HPV) genotypes associated with laryngeal papilloma
}

\author{
G CORBITT, * A P ZAROD $\ddagger$ J R ARRAND, $\dagger$ M LONGSON,* W T FARRINGTON $\dagger$ \\ From the *North Manchester Regional Virus Laboratory, Manchester Royal Infirmary, the $\dagger$ Department of \\ Molecular Biology, Paterson Laboratories, and the $\ddagger$ Department of Otolaryngology, Christie Hospital, \\ Manchester
}

SUMMARY Biopsy specimens from 14 patients treated for laryngeal papillomatosis were tested for the presence of human papillomavirus (HPV) genome by the technique of DNA-DNA hybridisation. According to the age of initial presentation, cases were subdivided into juvenile (less than 16 years) and adult onset (older than 16 years) groups. Histological investigation confirmed that it was impossible to distinguish the groups on this basis. Molecular virology using both dot blot and Southern transfer techniques showed that 10 cases carried the HPV type 6 genome, three cases HPV type 11, and in one case no HPV DNA was detected. All six adult onset cases carried HPV 6 sequences while the juvenile onset group comprised four HPV6 and three HPV 11 cases. In the juvenile onset group more females were affected; in the adult onset group more males were affected. Two of the patients shown to have HPV type 11 sequences in their biopsy material were the most resistant to treatment. One of the adult onset cases subsequently developed a squamous cell carcinoma of the larynx in which HPV 6 DNA was detected. As far as we know this is first time that HPV-DNA has been confirmed in laryngeal papilloma undergoing malignant change.

Squamous papillomas of the larynx are a serious clinical problem because of their location, resistance to treatment, recurrence and tendency to spread throughout the respiratory tract. ${ }^{1}$ The most common age of onset is during the first five years of life, ${ }^{2}$ and it is strongly suspected that such multifocal juvenile onset laryngeal papilloma originates from a perinatal infection from mothers with condylomatous lesions. ${ }^{3}$ Oral and genital papillomata carry scant numbers of virus particles making specific diagnosis by electron microscopy $^{45}$ and immunopathology ${ }^{67}$ very difficult.

Molecular biological techniques have permitted the recognition of $32 \mathrm{HPV}$ genotypes ${ }^{8}$ most of which have been molecularly cloned and these cloned probes can be used to detect HPV sequences in clinical material.

We were fortunate in having a relatively large group of patients with recurrent laryngeal papilloma who were receiving treatment at Christie Hospital, and it was decided to investigate a series of these patients for the presence of HPV genome as and when they required surgical removal of their papillomata.

Accepted for publication 3 September 1987

\section{Material and methods}

The study population comprised 14 patients who had been referred for treatment of recurrent laryngeal papilloma. All patients were examined under general anaesthesia by direct microlaryngoscopy to assess the papillomatous infection of the larynx and hypopharynx. Using punch biopsy forceps, tissue samples were taken for conventional histological investigation and for molecular virology studies. Care was taken not to spread tumour tissue, and the biopsy area together with other areas of papilloma were treated by carbon dioxide laser vapourisation. Biopsy samples for virology were frozen immediately in liquid nitrogen.

Tissue samples were recovered from liquid nitrogen and pulverised in the frozen state for 60 seconds using a Braun Mikrodismembrator (FT Scientific Instruments Ltd, Gloucester). Following this the DNA was extracted from nuclear pellets following the method of Favaloro et al. ${ }^{9}$ DNA extracts were stored at $-20^{\circ} \mathrm{C}$ until required.

DNA assays were performed on each sample using a fluorimetric mithracin dye binding assay ${ }^{10}$ and results 
were read on a Perkin-Elmer MPF-2a spectrofluorimeter.

Human papillomavirus genotypes $6,11,16$ and 18 cloned into the plasmid pAT 153 were kindly supplied by Dr DJ McCance, department of microbiology, Guy's Hospital.

Plasmids were transfected into Escherichia coli HB101, amplified, purified and the HPV inserts recovered using standard procedures. " All cloned DNA probes were stored in Tris-edetic acid buffer (10 $\mathrm{mM}$ Tris, $1 \mathrm{mM}$ edetic acid, $\mathrm{pH} 7.9$ ) at $-20^{\circ} \mathrm{C}$.

All tissue samples were initially examined by dotblot hybridisation ${ }^{12}$ using a BRL Hybridot apparatus (BRL Ltd, Paisley, Scotland). Nitrocellulose membranes (Scleicher and Schull-Anderman, East Molesey, Surrey) $(0.45 \mu)$ were presoaked in distilled water and equilibrated in $20 \times \mathrm{SSC}(3 \mathrm{M}$ sodium chloride, $0 \cdot 3 \mathrm{M}$ trisodium citrate). Patient DNA (2-5 $\mu \mathrm{g})$ was rendered single-stranded by denaturing for 10 minutes with $0.3 \mathrm{~N} \mathrm{Na0H}$ at room temperature and samples were then chilled, diluted with an equal volume of cold $2 \mathrm{M}$ ammonium acetate, and applied as $75 \mu$ l volumes to four replicate wells on the Hybridot apparatus. After binding all wells were washed with $100 \mu \mathrm{l}$ of $20 \times \mathrm{SSC}$ and the filters were air dried and baked at $80^{\circ} \mathrm{C}$ under vacuum for two hours. Filters were then pre-hybridised using a non-fat dry milk (Blotto) technique ${ }^{13}$ for 24 hours at $65^{\circ} \mathrm{C}$. After this filters were cut into strips, bagged with the appropriate radiolabelled probe which had been rendered single stranded by boiling, and DNA-DNA hydridisation was performed at $65^{\circ} \mathrm{C}$ overnight in the same Blotto solution.

Filters were washed for two half hour periods in $0.25 \%$ Blotto, $2 \times \mathrm{SSC}$, and $0.1 \%$ sodium dodecyl sulphate at room temperature, followed by two 30 minute high stringency washes in $0.6 \times \mathrm{SSC} / 0.1 \%$ sodium dodecyl sulphate at $61^{\circ} \mathrm{C}$. After drying the filters were put to film and autoradiography carried out at $-70^{\circ} \mathrm{C}$.

Where the amount of DNA obtained permitted, the identity of the HPV DNA was confirmed by Southern transfer analysis ${ }^{14}$ following digestion of the cellular DNA with the restriction enzyme Pst 1 .

Cloned HPV DNA was labelled with ${ }^{32} \mathrm{P}$-dCTP in vitro by nick translation. ${ }^{15}$ DNA $(1 \mu \mathrm{g})$ was incubated with $30 \mu \mathrm{Ci}$ of labelled nucleotide in the presence of 2.5 $\mu \mathrm{M} \mathrm{d}$ ATP, $\mathrm{d}$ GTP, and d TTP and $5 \mathrm{U}$ of DNA polymerase 1 (Kornberg) using a standard nick translation buffer with the addition of $0.005 \mu \mathrm{g} / \mathrm{ul}$ bovine serum albumin (fraction $\mathrm{V}$ ). The total volume of the reaction mixture was $40 \mu \mathrm{l}$. Incubation was at $12^{\circ} \mathrm{C}$ for three hours after which unincorporated label and nucleotides were separated by fractionation on Sephadex G75 (Pharmacia Ltd, Milton Keynes) using $\mathrm{TE}$ as eluant.
Table Laryngeal papilloma (12 cases)

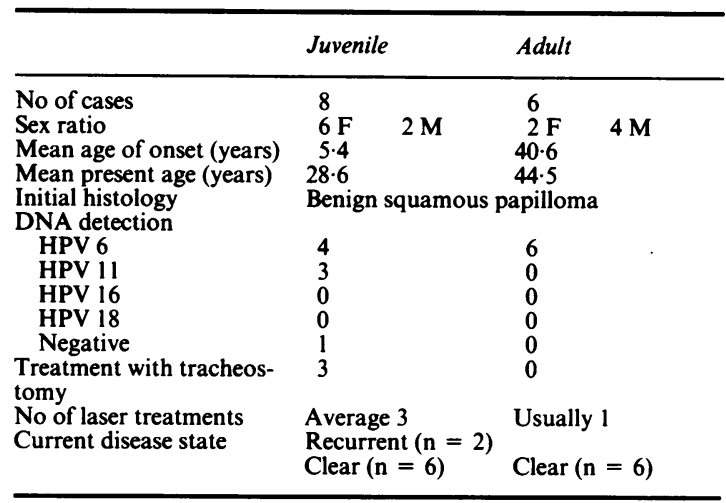

\section{Results}

The results are presented in the table: cases were divided into juvenile onset (eight cases) in whichpapillomata appeared before the age of 16 and adult onset (six cases) in which the first appearance of laryngeal lesions was after the age of 16. Affected females predominated in the juvenile onset group and a reverse trend occurred in the adult onset group. Mean ages of onset and mean presenting ages were calculated for each group.

The cases showed a similar histological picture of benign squamous papilloma, showing a stratified squamous epithelium with a vascular connective tissue core. The prickle cell layer showed severe hyperplasia, the epithelium showed abnormal differentiation, and there was a characteristic appearance of koilocytic cells showing irregularly shaped nuclei surrounded by clear areas.

Of the adult group, two cases have shown further histological progression of the disease. One of these has severe epithelial changes showing dysplasia, keratosis, and acanthosis; the other developed a squamous cell carcinoma of the larynx which required radical radiotherapy.

All specimens were examined by dot blot hybridisation (figs $1 \mathrm{a}$ and $\mathrm{b}$ ), and with one exception (lane 10) were found to be positive for either HPV 6 or HPV 11 DNA under conditions of high stringency. Some cross reactivity was observed in each direction due to the high degree of genome sharing between these two viruses - that is, strong type 6 reactions yielded weaker reactions to type 11 probes and vice versa. No binding was observed using probes for HPV 16 and HPV 18. These were included for no other reason than that they were available as a result of other project work being undertaken and gave an indication of the specificity of the observed reactions under the conditions of test. DNA extracted from normal human cervical tissue 
Figs 1 a, b Dot blot hybridisation with ${ }^{32}$ P-labelled probes (HPV 6, 11, only shown). Overnight exposure. Patient DNA extracts only. Positive standards using cloned purified HPV DNA included on each dot blot run. No standard negative laryngeal tissue was available for test.

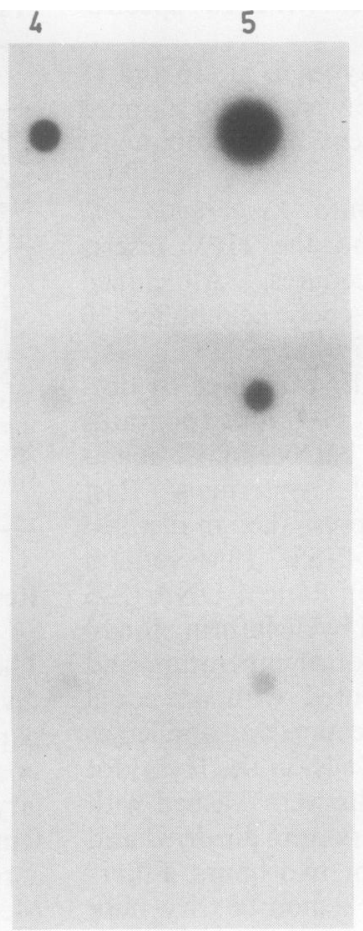

6

7

HPV 6

HPV 11

HPV 6

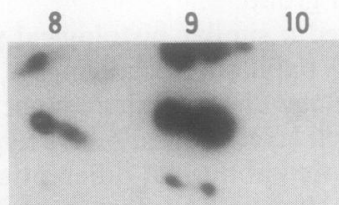

HPV 11
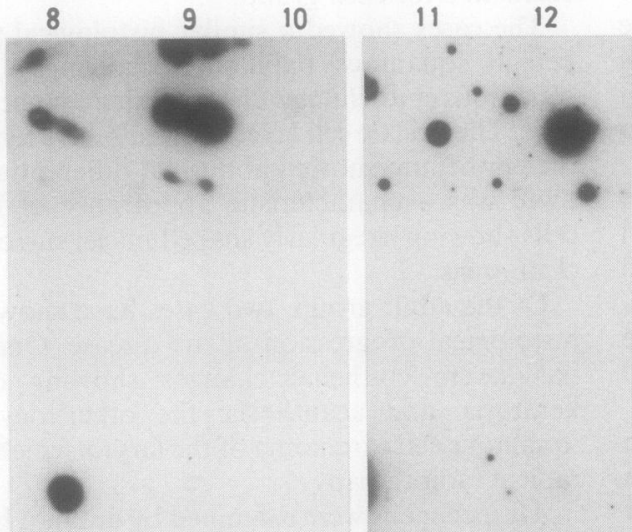

13

14
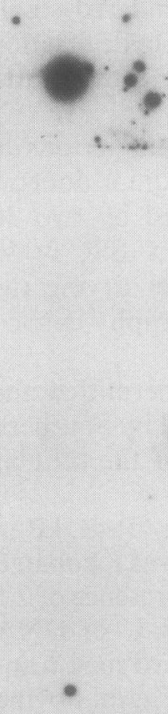
was used as negative control material and did not indicate any probe binding with any of the four HPV DNA's used.

Serial dilutions of probe DNA each combined with $5 \mu \mathrm{g}$ of DNA extracted from normal cervical tissue were prepared and dot blotted and this indicated that the test was capable of detecting as little as $5 \mathrm{pg}$ of HPV DNA.

Southern analysis of DNA from 12 of the 14 patients in the study was undertaken following digestion of the DNA with Pst1. Probing was only undertaken for HPV 6 and HPV 11 and control positive preparations were concocted by mixing $1 \mu \mathrm{g}$ of probe DNA with $10 \mu \mathrm{g}$ of normal cellular DNA followed by digestion with Pst1. Negative material alone was not included as this had previously been shown not to yield any reaction when run by Southern analysis. Washing was again carried out under conditions of high stringency. Fig 2 shows the results of probing 11 of the patients positive for HPV DNA by dot blot hybridisation, using an HPV 11 probe. The specific recognition patterns were clear. Similar results were obtained with HPV 6 probing, although the patterns were not so uniformly consistent as the HPV 6 genotype exists as a number of restriction subtypes. The restriction pattern of the HPV 6 probe DNA following digestion with $P s t 1$ yielded fragments of about 3850,1750, 1300 and 1000 base pairs which all appeared on autoradiographs of patients DNA digests. Seven of the patients looked at by Southern analysis showed this restriction pattern; two gave a different pattern of reactivity (each the same and shown after washing filters at high stringency). The restriction pattern of the HPV 11 probe DNA was more complex yielding fragments of about 1850,1550, 1450, 1050, 750 and 500 base pairs. Of these, only four $(1550,1450,1050$, 750) appeared on autoradiographs of both probe DNA and patient DNA digests (fig 2).
In conclusion, all six adult onset cases showed the presence of HPV 6 DNA. Four of the juvenile onset cases were also found to carry HPV 6 DNA while three others were HPV 11 positive and in one case no evidence of hybridisation with any of the chosen probes was seen.

Three patients in the juvenile group required tracheostomy at some stage of the disease but none of the adult onset group had obstructive airway problems.

The juvenile onset patients required an average of three laser treatments to obtain satisfactory control of the disease whereas in the adult group all but one received only one treatment.

At the time of writing all adult cases and three of seven juvenile cases remain clear of obvious disease; the remaining juvenile cases are still experiencing recurrences.

\section{Discussion}

The 14 cases of laryngeal papilloma represented a clinically important study group as the disease is only rarely seen in otolaryngological practice. Interestingly, males were more commonly affected in the adult onset group and females in the juvenile onset group. The male preponderance in adult onset disease has been noted previously ${ }^{16}$ although in the juvenile onset group the sex ratio is usually equal. Discrepancies, of course, can easily arise when examining small numbers.

The mean age of presentation of 5.4 years in the juvenile onset group correlates well with that of other studies $^{218}$ in that symptoms are usually present before the age of 5 years. The high mean presenting age of 28.6 years confirms the fact that the disease is resistant to conventional methods of treatment and continues to give problems after puberty, although some patients

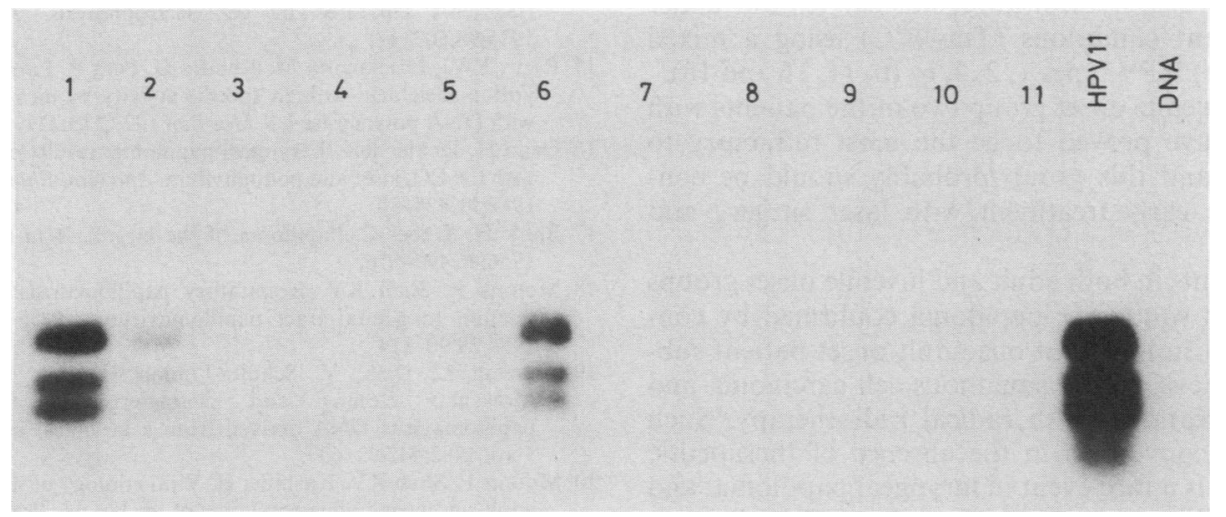

Fig 2 Southern blot hybridisation with 'P-labelled HPV 11. Specific activity about $5 \times$ $10^{7} \mathrm{cpm} / \mu \mathrm{g}, 14$ days' exposure time. All DNA samples were digested with restriction enzyme Pst I, electrophoresed and transferred to nitrocellulose by standard techniques. Lanes 1, 2, and 6 show three patients found to have evidence of HPV II DNA by dot blot, and lane 12 shows restriction pattern of purified cloned HPV 11 DNA used as probe. 
do exhibit a greatly diminished rate of tumour growth or complete remission.

The longer period of papilloma infection of the larynx in the juvenile onset group and the more aggressive nature of the papilloma is reflected in the fact that three of these patients required a tracheostomy at some stage of the disease; none of the adult onset group had obstructive airway problems. The more aggressive behaviour of the papilloma in juveniles has also resulted in the patients requiring more laser treatments than those in the adult onset group.

Since the development of cloned HPV probes and their use in DNA hybridisation studies there have been few published reports of HPV genotypes in laryngeal papilloma. Gissman et al ${ }^{19}$ purified papillomavirus DNA from a case of juvenile onset laryngeal papilloma by cloning into bacteriophage $\lambda$ and determined this to be a new type on the basis of its sharing only $25 \%$ genome homology with HPV 6 . They classified this new type as HPV 11 and have since shown it to be associated with genital warts and with seven of 14 laryngeal papillomas examined.

Mounts et al, ${ }^{20}$ examined DNA from 12 juvenile onset and eight adult onset cases of laryngeal papillomas using a molecularly cloned HPV 6 probe. In all cases HPV 6 DNA was identified on the basis of size, restriction endonuclease analysis, and homology under stringent conditions. Restriction endonuclease analysis showed at least four subtypes associated with the disease. There is much less viral DNA in laryngeal papilloma than in condyloma and this has probably impeded the detection and isolation of papillomavirus genome in these lesions. ${ }^{18}$

All our adult onset cases were associated with HPV 6 . In the juvenile onset group four cases carried the HPV 6 genome, three cases the HPV 11 genome, and in one case no evidence of HPV genome of the types investigated was found. This latter finding was also confirmed when hybridisation was carried out under non-stringent conditions $\left(\mathrm{Tm}-40^{\circ} \mathrm{C}\right)$ using a mixed HPV probe) HPV types 1, 2, 4, 6, 10, 11, 16 and 18).

In the juvenile onset group two of the patients with HPV 11 have proved to be the most refractory to treatment and this group probably should be considered for early treatment with laser surgery and interferon.

All patients in both adult and juvenile onset groups and benign squamous papilloma confirmed by conventional histology, but one adult onset patient subsequently developed a squamous cell carcinoma and required treatment with radical radiotherapy. Such malignant conversion in the absence of therapeutic irradiation is a rare event in laryngeal papilloma, and we believe this to be the first time that HPV DNA has been confirmed in a laryngeal papilloma undergoing malignant change.

Another adult onset patient who has severe epithelial changes exhibiting dysplasia, keratosis, and acanthosis is being closely monitored prospectively. Both these patients had HPV 6 DNA associated with their lesions.

We acknowledge the financial assistance given by both the Cancer Research Campaign and the Research Grants Committee of Central Manchester Health Authority.

\section{References}

1 Strong MS, Vaughan CW, Healy GB. In: Healy GB, McGill TJI, eds. Laryngo-tracheal problems in the paediatric patient. Springfield, Illinois: Charles Thomas: 88-95.

2 New GB, Erich JB. Benign tumours of the larynx. Arch Otolaryngol 1938;28:841-910.

3 Quick CA, Faras A, Krzyzek R. The aetiology of laryngeal papillomatosis. Laryngoscope 1978;88:1789-95.

4 Praetorius-Clausen F, Willis J. Papovavirus-like particles in focal epithelial hyperplasia. Scand J Dent Res 1971;79:362-65.

5 Lutzner M, Kuffer R, Blanchet-Bardon C, Croissant O. Different papillomaviruses as the causes of oral warts. Arch Dermatol 1982;118:393-9.

6 Costa J, Howley P, Bowling H, Howard R, Bauer WC. Presence of human papilloma viral antigens in juvenile multiple laryngeal papilloma. Am J Clin Pathol 1981;75:194-7.

7 Lack EE, Jenson AB, Smith HG, Healy GB, Pass F, Vawter GF. Immunoperoxidase localisation of human papillomavirus in laryngeal papillomas. Intervirology 1980;14:148-56.

8 Singer A, Campion MJ, McCance DJ. Human papillomavirus. $\mathrm{Br}$ J Hosp Med 1985;34:104-8.

9 Favaloro J, Treisman R, Kamen R. Transcription maps of polyomavirus specific RNA: analysis by two-dimensional nuclease mapping. Methods Enzymol 1980;65:718-49.

10 Hill BT, Whatley S. A simple, rapid microassay for DNA. FEBS Letts 1975;56:20-3.

11 Maniatis T, Fritsch EF, Sambrook J. Molecular cloning, a laboratory manual. New York: Cold Spring Harbor Laboratory, 1982.

12 Kafatos FC, Weldon Jones C, Efstratiadis A. Determination of nucleic acid sequence homologies and relative concentrations by a dot-hybridisation procedure. Nucleic Acids Res 7:1541-52.

13 Johnson DA, Gautsch JW, Sportsman JR, Elder JH. Improved technique utilising non-fat dry milk for analysis of proteins and nucleic acids transferred to nitrocellulose. Gene Anal Techn 1984;1:3-8.

14 Southern EM. Detection of specific sequences among DNA fragments separated by gel electrophoresis. J Mol Biol 1975;98:503-17.

15 Rigby PWJ, Dieckmann M, Rhodes C, Berg P. Labelling deoxyribonucleic acid to high specific activity by nick translation with DNA polymerase I. J Mol Biol 1977;113:237-51.

16 Dedo H, Jackler RK. Laryngeal papilloma: results of treatment with the $\mathrm{CO}_{2}$ laser and podophyllum. Ann Otol Rhinol Laryngol 1982;91:425-30.

17 Bjork H, Weber C. Papilloma of the larynx. Acta Otolaryngol 1956;46:499-516.

18 Mounts P, Shah KV. Respiratory papillomatosis: etiological relation to genital tract papillomaviruses. Prog Med Virol 1984;29:90-114.

19 Gissman L, Diehl V, Schultz-Loulon HJ, zur Hausen H. Molecular cloning and characterisation of human papillomavirus DNA derived from a laryngeal papilloma. $J$ Virol 1982;44:393-400.

20 Mounts P, Shah KV, Kashima $\mathrm{H}$. Viral etiology of juvenile- and adult-onset squamous papilloma of the larynx. Proc Natl Acad Sci USA 1982;79:5425-9.

Requests for reprints to: Dr G Corbitt, North Manchester Regional Virus Laboratory, New Holzel Laboratory, Booth Hall Children's Hospital, Charlestown Road, Manchester M9 2AA, England. 